Sergej V. ULJANOV*

Business and Law Faculty, University “Union - Nikola Tesla”, Belgrade, Serbia

Ana G. MATOVIC**

College of Economics Pec-Leposavic, Serbia

\title{
EVIDENCES AND EVIDENTIARY ACTIONS IN "RUSKAIA PRAVDA”
}

\begin{abstract}
The source of old Russian law named as "Ruskaia Pravda", being the essence of the article, shows a kind of look of Russian society at the edge of early and developed Middle Ages. The author tends to present hierarchy in relations of social categories established in first Russian entities, just as their structure caused by geopolitical influence of leading states of Scandinavia and Byzantine. The article begins with analyzing the external factors of creating initial steps of Russian statehood. It is followed by the author's pointing out of importance of Russian medieval legislative corner-stones to make importance of "Ruskaia Pravda" stressed out considering preserving of Russian society core values of that period. Substantially, the author pays attention to evidences quoted in "Ruskaia Pravda", as being special reflection of medieval man's understanding of social values just as being key factors of these values defending. Legal and institutional particularity of medieval Russia is illustrated by the author in this article by detailed overview of normative solutions placed in "Ruskaia Pravda", as one of the main governmental pillar having to do with forming early sociopolitical milieu of medieval Russia.
\end{abstract}

Key words: evidences, evidentiary actions, Ruskaia Pravda, Criminal Procedure Law, the Middle Ages.

\section{INTRODUCTION}

Being settled on the traffickers' route, spearheaded by Scandinavian merchants' swords up to the regions governed by Byzantine in the early $9^{\text {th }}$ century $\mathrm{AD}$, divided tribes of Eastern Slavs began to form first bigger communities in the areas of nowadays Kiev, Pereyaslavl, Chernigov, Smolensk, Polotsk

* Docent, sputnik970@gmail.com

**Teaching Assistant, matovic.anna@gmail.com 
and Rostov. (Miljukov - Senjobos - Ezenman 1939: 52) Influenced by trafficking flows and having active role in exchange of goods between Scandinavian West and Byzantines East, the early medieval tribal organization of Eastern Slavs was overpowered and primitive strongholds grew up in first little towns named as gorodischa being centers of merchant activities. (Jelačić 1929: 7) As stockpiles, these fortified towns were targeted very often by armed Scandinavian merchants' groups to be ransacked and used as sources for merchants' plunder to be sold to Byzantine. As times went by, even the very Eastern Slavs joined the ransacking and afterward attacks on Byzantine lands together with Viking raiders. Trafficking connections developed more and more, so little towns from stockpile level reached the form of important and big merchant centers having a rich offer of consumer goods derived from exchange of grain for fur with Finnish tribes to exchange of rare spices, gold, vine, silk and fruits purchased from Byzantines and Arabian traders for timber, wax and honey gotten from upper river flows of Volga and Dnieper. (Jelačić 1929: 13)

Paganism of Viking ransacking traders and Eastern Slavs got along in prevailed degree considering polytheistic pantheons, so there were no cultural differences mattered. This fact enabled ethnical synergy making Viking mercenaries to organize and protect trading having Slavs joined their armed groups, just like making Slavs to engage Vikings in their towns' defense. It was not rare for towns' mayors to be Scandinavians named as konung who did not ask for salary but to be paid in goods. (Miljukov - Senjobos - Ezenman 1939: 52) According to their Slavic name Varyazi, they put their Viking wandering spirit into framework of life in towns placed by the rivers ran through the regions of nowadays Russian Federation and settled down among Slavs. (Miljukov - Senjobos - Ezenman 1939: 52-54) In the middle of the $9^{\text {th }}$ century in the lands of Eastern Slavs principalities of Varyazi have been established in the towns of Novgorod, Beloosero, Izborsk, Polotsk, Turov and Kiev. (Miljukov - Senjobos - Ezenman 1939: 53)

On the crossroads of the $9^{\text {th }}$ and the $10^{\text {th }}$ centuries Varyag-Russian prince known as Rurik (Jelačić 1929: 10) forced his rule in Novgorod (The Russian Primary Chronicle, Laurentian Text 1953: 60) and his successors governed Kiev and Smolensk establishing domination of Ruriks' dynasty along rivers Dnieper, Don, Volga, Dvina, Volkova and Ilmeny lake, as vital areas transited by trading routes connected West and East just like Asia with Middle Europe, too. (Miljukov - Senjobos - Ezenman 1939: 53) Political and economic expansion of Ruriks' dynasty played a role of roots for Russian state and first signs of Russian society institutionalization in the early Middle Ages. (Jelačić 1929: 18) 


\section{INSTITUTIONAL PREDISPOSITIONS OF RUSSIAN MEDIEVAL SOCIETY}

Eastern Slavic tribes were looking for fertile land because vast forested areas were hard to be exploited for agricultural matter and so they reorganized themselves into families grouped as communities. As consisted of relatives and nonrelatives, communities were joined like volost. Communities were led by families' masters gathered in council, also known as veche, where they discussed about most crucial issues considering community and where their leader was to be chosen. (Miljukov - Senjobos - Ezenman 1939: 51, 56)

First cities appeared due to increasing of population triggered by wealth derived from progressive trading and it caused a new social class of traders. Henceforth, these cities became centers governing the surrounding areas and it was beginning of city municipalities. Subsequently, previous social structure based on tribes had to be changed and council was to played steering role at the level of municipality inhabited by citizens and villagers from close villages represented in the council, as well. (Miljukov - Senjobos - Ezenman 1939: 55-56)

At dawn of the $11^{\text {th }}$ century the old Chronicles of Nestor the Monk of Pechersky Monastery in Kiev and Silvester the Abbot of Vidubitsky Monastery in Kiev were source for the expression all-Russian-land which meant the lands ruled by princely dynasty of Ruriks. Totality of the territory were split into provinces named as volosti governed by princes in the way of delegating power on so-called druzhina manned by prince's guarding warriors, older citizens and the most confident people of Kiev. (Miljukov - Senjobos - Ezenman 1939: 51) In the province of Kiev this kind of governing social class was the most powerful and this province was the first one named as Russian-land with the other Eastern Slavs' provinces, tended to Kiev, following it. (Miljukov - Senjobos - Ezenman 1939: 55) In conquered areas, prince of Kiev was not up to replace the local squire if he admitted Kiev supreme governing, yet prince did nominate one of his relative to be a governor named as posadnik (The Russian Primary Chronicle, Laurentian Text 1953: 254) more often. (Miljukov - Senjobos - Ezenman 1939: 54) Tribute paid by ruled province to Kiev was collected by the governor, prince and princely guard. Also, the tribute was a salary to princely guard dealt with protecting conquered and governed cities and trading routes connected them to markets.

Over time, princely governing was changed its primary function considering defending and protecting cities becoming more like supreme and judicial. It is ought to be mentioned that this transformation of governing focus was triggered by Byzantines perception of supreme leader's divine origin implemented into first Russian state organization by the influence of Christian church. (Miljukov - Senjobos - Ezenman 1939: 55-56) At the certain point, Church 
established to Eastern Slavs the unity of belief and clerical hierarchy up to the level mattered Byzantines normative system as one of having influence to princely and laic courts through active role of clerical courts. (Miljukov - Senjobos - Ezenman 1939: 56)

In the $11^{\text {th }}$ century, princely guard became institutional ground for governors and judges elected by prince. Besides the importance of tax collection and judging, princely guard brought up a new class of boyars gathered in duma to make decisions (The Russian Primary Chronicle, Laurentian Text 1953: 116) together with prince related to the most important issues for political life in the governed provinces. (Jelačić 1929: 26) A kind of counterbalance was made by cities' councils of families' masters authorized to decide to expel prince from the very city, if argued in concreto. (Miljukov - Senjobos - Ezenman 1939: 62) One can conclude that institutional predisposition of Russian medieval society were created in sociopolitical relations, connections and antagonism of combined influences considering unity and conflicts in singular governing role of prince, aristocratic demonstration of boyars' duma power (The Russian Primary Chronicle, Laurentian Text 1953: 116) and cities' mayors, just like in democratic exposing of citizens gathered in cities' councils. (Jelačić 1929: 26)

It is necessary to conceive the inception of particular legislative awareness, under above mentioned social, economic, confessional and political conditions, which gave birth to an idea about normative unification aimed to regulate different segments of social life in the first steps of Russian state development, at transition from the Early to the High Middle Ages.

\section{LEGISLATIVE POWER OF "RUSKAIA PRAVDA"}

In the political surrounding of an aggressive fighting-trading expansion of $\mathrm{Vi}$ king armed groups, Byzantines military and political dominant presence followed by strong and constant confessional influence and Arabian economic involvement through exporting rare products hard to be purchased to the cities' markets of Russian medieval state, it became necessary to regulate relations among various social classes that formed structure of early staged Russian society.

According to witnessing of Arabian travel writers and merchants (Marvazi 1932: 26, 35-36, 112-120; Yahua 1932: 423-424, 458), Byzantines missioners and statesmen (Porphyrogenitus 1819: 49, 52-53, 57; Cedrenus 1838: 438; Psellus 1928: 11, 55-56, 79), just as to written chronicles of Russian monks, delicts have been mentioned in the $9^{\text {th }}$ and the $10^{\text {th }}$ centuries. As illegal actions one implied following offences: thefts, affrays and murders. However, these criminal activities were not marked with standardized terminology, but ad hoc with common term as crimes. 
Old Russian Code "Ruskaia Pravda", as fundamental source of medieval Russian law, ${ }^{1}$ has regulations which determine criminal offence generally as obida. "Ruskaia Pravda" has three groups of regulations that one can treat in the form of versions. First one is, most probably, created in the time of Yaroslav the Wise ${ }^{3}$ having eighteen provisions. Second one gathers provisions dated from the time of Yaroslav's sons reign, ${ }^{4}$ while third one has just articles annotated as $42^{\text {nd }}$ and $43^{\text {rd }}$. If certain way of behaving is to be punished it means in essential that it is illegal. The very presence of sanction caused awareness of fact whether some action was allowed or it was treated as criminal offence.

In the first phase of establishing Russian state punishment was following violation of princely law, usually, because the law was made of regulations which reflected legislative expression of customs, religious and ethical rules sanctioned if not followed. Nevertheless, at the end of Middle Ages customs led a way for punishment proceedings to be created in the first Russian principalities and rural communities. Medieval Russian lawmaker was oriented to protect individuals who were more endanger due to class domination in social structure affected heavily way of life in tribal society organized traditionally.

Medieval Code "Ruskaia Pravda" prescribes two kind of delicts, ones against person and others considering property. First group relates to insult, injury, affray and murder, while the second one forbids trespassing, illegal use of someone else's property, theft and robbery. (Nikolić 2000: 92) Prevailing number of regulations of "Ruskaia Pravda" sticks to the problem of theft with specifying possible protected values in details. Lawmaker defined offender to restitute total loss to damaged party in the case of theft committed with paying fine. Oldest sources of Russian history indicate that murder of clan member is followed by revenge of his relatives. The revenge was to be done at the very crime scene according to contracts made between Russian principalities and Byzantine. In the $10^{\text {th }}$ century there were bans on blood revenge implemented. It was replaced by ransom, gradually. In the oldest version of "Ruskaia Pravda" the closest relatives are recognized to execute blood revenge, solely. Adopting of orthodox Christianity influenced on definite revoking of blood vengeance category from the ways of executing sentences in medieval Russian sociopolitical entities. From the institutional aspects of governing stakeholders, the murder was enormous

1 It was discovered by V. N. Tatischev in 1738 when examined a particular chronicle written in Novogorod in the mid- $15^{\text {th }}$ century.

2 Comparing to Serbian medieval law (Saint Sava's Charter to Saint Nikola Monastery in Vranjani, from 1233 and Dusan's Code, from 1349 and 1354), this term had the next meanings: guiltiness, evil, debt, violation, acting out of spite and wrongdoing.

3 Yaroslav I, known as Wise, having Christian name George used to be great prince of Kiev Russia (978-1054). He ruled from 1016 to 1054 (with break in period 1018-1019).

4 Those were Izyaslav I (1025-1078), Svyatoslav II (1027-1076) and Vsevolod I (1030-1093). 
sin and its punishing was taken over from individuals by the state, so that was the reason of allocating level of competence to proceed from victim's relatives to the abstract degree of entire social community ruler's political power. Clerical point of view, though, treated blood vengeance as a violating form of God's commandment "You shall not kill" having a stand that blood revenge as a sin was as heavy as murder revenged. (Nikolić 2011: 245-246) In accordance with the Chronicle of monk Nestor: "Vladimir has been living in the fear of God. And robberies multiplied. And episcopes told to Vladimir: 'There one has a vast number of robbers. Why don't you punish them by death?' He replied to them: 'I am afraid of doing sin'." (The Chronicle of Nestor the Monk of Pechersky Monastery in Kiev 997: 127) The quoted can be a reason why prince Vladimir, after adopting Christianity at the end of the $10^{\text {th }}$ century, banned death sentence for murder even though he had implemented it by device of Byzantines high ranking priests, previously.

One can conclude that regulations of "Ruskaia Pravda" focus, above all, fine to be paid and death sentence as a way of punishment is not recognized in the normative system of the Code. Yet, Arabian travel writers in the $9^{\text {th }}$ and the $10^{\text {th }}$ century indicated their impressions of having robbers and thieves hanged in medieval Russia and that death sentence were replaced with expelling of murders in the far parts of principality of that time, too.

At the sunset of the $10^{\text {th }}$ century, death sentence was replaced by fine in Russian medieval society, completely. Named as vira, fine was to be paid for murder of free man and it was defined in amount of 40 silver grivnas in cases like this. If slave was killed, punishment was not paying off vira but compensation limited by price paid for slave when bought. In the most of cases, the amount of vira was not possible to be paid by citizens' own means and it caused solution in the way of implementing institute of dirkaja vira. (Nikolić 2011:248) This penological phenomenon enabled all community ${ }^{5}$ members to gather their means and pay off ransom for murder committed. The amount of dirkaja vira was defined for obligation of community punished member in concreto or when offender was not found. Prodazha was the most presented modus of fine. As a type of sanction, it was a unique confirmation that offender belonged de iure to the social category of free men.

We deem needed to be pointed out that "Ruskaia Pravda" by not defining death sentence, in the period of transition from the Early to the High Middle Ages and founding of first Russian municipalities as sociopolitical embryos of Russian state, just as with having fine as punishment prevailed making blood vengeance overcome as retrograde matter of civilization, represents an advanced legal base for regulating and exercising rights and obligations of every subject in well branched classed social structure of first forms of Russian medieval state organization.

5 With a meaning of municipality in the socio-organizational sense. 


\section{EVIDENCES AND EVIDENTIARY ACTIONS DETERMINED NORMATIVELY}

Before getting into normative structure of "Ruskaia Pravda" which has to do with determining of evidentiary actions, it is necessary to make a quick overview relates to sociohistorical conditions of creating the Code. Up to the end of the $10^{\text {th }}$ century, in early Slavic states dominated customary law in accordance to the Chronicles, with possible legendary character. A few decades later, attempts to codify customs resulted in bringing first $\operatorname{Acts}^{6}$ considering different legal matters with penal law and penal proceedings included, primarily.

Depends on geographic location of appearance, old Slavic states were exposed to pressures and influences of Byzantines ruling as much as of German and Scandinavian entities. Under such conditions of international scene of that time, the Code "Ruskaia Pravda" came up as first one codifying Russian customary law.

By being first to determine special kind of evidentiary actions "Ruskaia Pravda" confirmed autochthonous development of legislation in early Slavic states. In its further analyzing, we are about to use the text of "The Laws of Rus' - Tenth to Fifteenth Centuries”, edited by author Daniel H. Kaiser, with direct indicating of provisions belong to this medieval Russian basic legal reference. (Kaiser 1992: 20-34)

The case of catching the offender on the spot is regulated by the Article $7^{\text {th }}$ of "Ruskaia Pravda". It states:

- "If [the homicide]* occurs without cause during an assault. If [a homicide] occurred during an assault without any provocation, then the people [in the community] do not pay for the murderer, but give him up with his wife and children for punishment and confiscation of his property."

The institute of witness is defined by fourteen provisions of "Ruskaia Pravda". For the sake of our analyzing we have selected the following ones:

- According to Article $21^{\text {st: }}$ "If [the accused] does not find the character witnesses he sought, then charges the complainant of the homicide [of which he himself is accused], then put them [both] to trial by ordeal of the hot iron."

- Article $31^{\text {st }}$ defines: "If a man either grabs a man to himself or shoves him away from himself, or strikes [him] across the face, or strikes [him] with a pole,

6 It is like Act of Czech prince Bzhestislav I, from the first half of the $11^{\text {th }}$ century, with provisions preserved in the Chronicle of Cosmas of Prague, from 1120.

7 According to the first Chronicle of Novgorod, "Ruskaia Pravda" was proclaimed in 1016 by great prince Yaroslav the Wise upon coming to Kiev principality to run his governing followed by enhancing of education and construction. Little bit later, "Ruskaia Pravda", having regulations of Yaroslav the Wise, was annexed by provisions of his sons Izyaslav, Svyatoslav and Vsevolod brought in Vishegorod in 1072.

* When put into brackets (like [ ]) means being edited by author. 
and [the victim] produces two eyewitnesses, then [the offender] is to pay three grivnas as a fine; if [the offender] is a Viking or some other foreign resident, then [the victim] is to produce all [the necessary] eyewitnesses, and the two of them take the oath."

- Article $47^{\text {th }}$ orders: "If someone claims money back [from someone]. If someone seeks repayment of money from another, [who] begins to deny [that he took that money], then [the creditor] brings witnesses against him, and they take an oath; then [the creditor] takes back his money; if [the borrower] did not give the money [back] for many years, then he is to pay three grivnas for the offense."

- In the line of Article $48^{\text {th }}$, it is written: "If some merchant gives [another] merchant money for local or foreign trade, then the merchant is not to take the money before witnesses; he needs no witnesses, but he himself is to take an oath if he shall deny [that he received any such money]."

- In accordance with Article 49 $9^{\text {th}}$ : "If someone places some goods for storage with someone, then no witnesses are necessary, but if he [later] begins to slander [the person who stored his goods by claiming] more [than he actually stored], then he who accepted the goods for storage is to take the oath [saying,] 'You left me only so much', for he rendered [the complainant] a service and stored his goods."

- Article 50 $50^{\text {th }}$ states: "If someone gives out money at interest, or [gives out] honey [on condition] of increased return, or grain [on condition] of increased repayment, then [the creditor] is to provide witnesses; whatever was agreed upon, that [the creditor is entitled] to take."

- Article $66^{\text {th }}$ determines: "[Free men] do not rely on the testimony of a slave; but if there be no free man [to testify], then, if necessary, refer to [the testimony] of a boyar's overseer, but do not rely upon other [slaves]. And in a suit [over] a small [sum] refer to [the testimony of an] indentured laborer."- Article $77^{\text {th }}$ prescribes: "If a thief is not [caught in the act], then [local residents] follow along the trail; if there be no trail [leading either] to a settlement or to a trading station, then [the residents of the community] do not relieve themselves of the responsibility for the posse, [but if] they do not continue on the chase or resist [looking for the thief], then they are to pay [compensation for] the theft and a fine; and the trail is to be pursued with other [free] men and with witnesses; if they lose the trail at a large roadway, and there be no settlement [nearby], or [if they lose the trail] in a deserted place, where there are neither settlements nor people, then [they] are not to pay a fine nor [compensation for] the theft."

- In the Article $85^{\text {th }}$ it is stated: "All these matters are decided by witnesses [who are] free men; if a witness be a slave, then do not put any credence in the slave's [word], but if a complainant wishes to take him, and says, 'I seize you on the word [of this slave], but I, and not the slave, seize you,' then put [the accused] 
to trial by hot iron; if [the accused] fails the trial, then [the accuser] takes his own property; if the accused is not convicted [by the ordeal], then [the accuser] is to pay him a grivna for the torture, since he took him on the basis of a slave's word."

Ordeal of the hot iron and the boiled water, besides Article $21^{\text {st }}$, is normatively scheduled in the next regulations:

- Article $22^{\text {nd }}$ stipulates: "The same [procedure obtains] in all cases of theft and [unsubstantiated] accusation; if there be no physical evidence, then force [the accused to trial by ordeal of the] hot iron for suits of one-half gold grivna; if the [value of the suit is] less, then [decide the case] by trial by water [in cases whose value] is less than two grivnas; if [the sum at issue is still] less, then put him [the accused] to trial by oath for his own money."

- Article $87^{\text {th }}$ anticipates: "If [someone] takes [another] to the iron ordeal on the word of free men, either because there are suspicions about him, or because [he was seen out] at night, and if perchance [the accused] is not burned [by the ordeal], then [the accuser] is not to pay him for torture, but whoever took him [to the ordeal] is to pay only the iron-ordeal fees."

Oath named as rota is an ordinary part of normative system established in "Ruskaia Pravda" and besides mentioned articles it is being provided with following, too:

- Article $37^{\text {th }}$ requires: "If someone purchases at market some stolen property, either a horse, or clothes or livestock, then [the purchaser] is to produce two free men or the customs officer [to confirm that he purchased the property at market]; if he maintains that he does not know from whom he purchased [the stolen property] then the eyewitnesses are to take the oath [on his behalf], and the complainant is to take his own property; and concerning property lost [and not recovered], the complainant may mourn [his loss], and the other party his [loss] of money [which he gave for the stolen property], since he does not know from whom he purchased [stolen goods]; if subsequently he recognizes [the person] from whom he purchased [that property], then he is to take back his own money, and that [newly discovered person] is to pay [the complainant] for the unrecovered property [as well] as a fine to the prince."

- By the Article 52 $2^{\text {nd }}$ : "If there be no witnesses [to the transaction] and [the sum loaned] is three grivnas, then [the creditor] is to take an oath for his [money]; if [the sum loaned] is more [than three grivnas], then say to him, 'You have erred, since you did not have witnesses' [present when the loan was contracted]."

- Article $115^{\text {th }}$ demands: "If someone meets [a man], not knowing [that he is] another man's slave, and either gives him directions or keeps him at his house, and [subsequently the slave] leaves him, then he shall take an oath that he did not know [lit., I did not know] that he was a slave; then no payment is required." 
- It is asked by the Article $118^{\text {th }}$ : "If someone buys another's slave, not knowing [that he belongs to another], then the [original] lord takes the slave, the other takes [back] his money, having taken an oath that he had purchased him without knowing [that he was another man's slave]; [if he had knowingly purchased him, then he has no claim to his money]."

Statement is anticipated by "Ruskaia Pravda" as important kind of proof inter alia by the Article $38^{\text {th }}$, too, which instructs:

- "If someone recognizes and takes back his own stolen slave, then he is to conduct the slave [by the confrontment process] through the money transactions until the third confrontment; then [the slave's owner] is to take another slave in place of his own slave, and give his property to the other party, who then continues until the last confrontment [when the original thief is discovered]; and this property is not cattle, so it is not possible to say '[I do not know] from whom I purchased [the slave]'; but [pursue the confrontment] on the [slave's] word until the end; and when the final thief is [discovered, the party identified at the third confrontment] is to return the slave [to his original owner] and take back his own [slave], and [the thief] is to pay all losses, and a twelve-grivna fine to the prince."

Importance of document as an evidence in the Code is called for in the Article $110^{\text {th }}$ in the next way:

- "Full slavery has three forms: if someone buys [a man] for up to half a grivna, and provides witnesses [to the sale], and then gives [even] a nogata [to the seller] in the presence of the slave himself; the second form of slavery: if [someone] takes a female slave [to wife] without having an agreement [stipulating that he will remain free], for if he takes [a slave to wife] with stipulations, then whatever he stipulated stands; the third form of slavery: [if a man becomes an] overseer without an agreement [stipulating that he will remain free] or if he accepts the key [to a man's household (i.e., becomes a steward)] without an agreement [stipulating that he will remain free]; for if he [accepted the duties] with stipulations, then whatever was stipulated stands."

The role of eyewitness, as a category of witness, is to be highlighted as we deem necessary to be and in "Ruskaia Pravda" it is scheduled in the next regulations:

- Article $29^{\text {th }}$ orders: "If a man bloodied or bruised [in a fight] comes to the [prince's] residence, then he need seek no eyewitness, but [the offender] is to pay him compensation of three grivnas; if there be no marks on him, then he is to bring an eyewitness [to confirm his account] word for word; whoever began the fight is to pay 60 kunas; if the man bloodied or bruised [by the fight] is guilty of having started the fight, and witnesses confirm [this], then that [his bruises] will serve as payment, since he [started] the fight."

- Article $40^{\text {th }}$ commands: "If they kill someone at the storeroom or [while he was engaged in] any other theft, then they kill [him] like a dog [and that is 
the end of the matter]; if they hold him until [morning] light, then they must conduct [the thief] to the prince's residence; if they kill him, and people have seen [the thief] tied up, then [the offenders] are to pay twelve grivnas for that." - Article $69^{\text {th }}$ states: "If someone steals a beaver, then [the thief] is to pay twelve grivnas."

If one compares last two provisions of "Ruskaia Pravda" by the amount of money showed through value of killed thief s life and stolen beaver, then it is to conclude that in this time in medieval Russia the beaver had overestimated value while the life of thief was almost worthless.

Recognition of persons and goods is defined in the following provisions of the old Russian Code:

- Article $32^{\text {nd }}$ requires: "If a [fugitive] slave is hidden [at someone's residence] and [the owners] announce [their loss] at the market square, and if within three days [the person with whom the slave is lodged] does not produce him, and [the slave's owner] learns [the slave's] whereabouts on the third day [or after?], then [the owner] is to take his slave, and [the party who hid the slave] is to pay three grivnas as a fine."

- In the Article $34^{\text {th }}$ is foreseen: "If someone loses a horse, or weapon, or clothes, and announces [his loss] in the market square, and subsequently recognizes [his lost property] in his own town, he is to take his own property back, and [the offender] is to pay him three grivnas."

- Article $35^{\text {th }}$ demands: "If someone recognizes his own [property] which he lost or was stolen from him, either a horse, or clothes, or livestock, then he is not to say, 'This is mine', but [rather] 'Come to a confrontment [to determine] where you acquired [the property]'; [if in the course of the confrontment process] it emerges who was guilty, then [the responsibility] for theft lies with him, and the [original] victim may take back his [property]; if some property was destroyed, then [the thief] is also to begin payment [for that]; if [the accused] is a horse thief, then [the community] is to give him up to the prince for punishment; if [the accused] stole from a storeroom, then he is to pay three grivnas."

Confrontment named as svod is inter alia provided by the following articles of "Ruskaia Pravda", as well:

- Article $36^{\text {th }}$ defines: "If [the confrontment] takes place within one town, then the complainant is to proceed until the end of the confrontment; if the confrontment leads through several districts, then [the complainant] is to proceed until the third confrontment; the person [discovered at the third confrontment] is to pay [the victim] in money for the property [i.e., for the physical evidence], and with this property [himself] proceed until the end of the confrontment, and the original complainant is to wait, and when the final confrontment is reached [and the original thief discovered], then [the offender] is to pay all costs and a fine." 
- Article $39^{\text {th }}$ orders: “And the confrontment is not to proceed from one's own town into another district, but [the accused] is to present witnesses or the customs officer before whom he purchased [the property in question], and the complainant is to take his property, and mourn the loss of [the other property which] disappeared, and [the accused] can mourn the loss of his money [which he paid for the stolen property]."

The regulations of this source of the old Russian law focus the matter of culprit's trace which is inter alia determined in the next way:

- Article $70^{\text {th }}$ indicates: "If the earth be dug up or [if there be some other sign] of a trap or net, then [the community] is to seek the thief among the [residents] of their own community or pay a fine."

The uniqueness of "Ruskaia Pravda" regulated, even, the costs of the ordeal as accuser's expenses if guiltiness not proved, just like uroke rotne (expenses of giving oath) depend on degree of social dangerousness of offence committed, and subsequently anticipated amateur jurors ${ }^{8}$ as relict of customary law, in the next provisions:

- Article $86^{\text {th }}$, which requires: "And [for administering] the iron ordeal pay 40 kunas, and five kunas to the prince's bodyguard, and a half-grivna to the prince's servitor [who administers the iron ordeal]; this is the schedule of fees for the iron ordeal, who receives [money] for what."

- Article $109^{\text {th }}$ : "And these are the fees for administering the oath: [for cases] involving homicides 30 kunas, [for cases] involving beehives 27 kunas; and the same [for violations] of plowland [borders]. And [for cases] involving manumission [of slaves] nine kunas."

\section{CONCLUSIONS}

Bringing this article to the end, we conclude that "Ruskaia Pravda" expressed broad implementation of irrational evidences highly respected in evidentiary actions performing in medieval Russia, obviously.

Svod and traces following, by all means, were among the most frequently used methods of providing the proofs. That was the exact way to find out an unconscienced possessor by performing svod, well known as legal custom of old Slavs from the earliest periods of their history. Traces following was, surely, connected to custom of paying vira, as a matter of institutionalized collective responsibility of community organized on municipal level.

In the lack of rational evidences, guiltiness was established by using of hot iron and pouring of boiled water, as well. The most dangerous criminal offences, as murder, required guiltiness to be proved by performing ordeal of the hot iron.

8 It relates to the Serbian term "sakletvenici". 
Evidentiary action was executed in the way the charged one had to carry hot iron or to walk over it. Then followed interpreting of burns without any details known. ${ }^{9}$

Ordeal of the water was realized by exposing parts of charged one's body to the hot water, but it was not the only mode of it. When it was up to the case of theft of stolen good valued 2 to 40 grivnas, charged one was to be tied and put on the surface of deep water. If he started to go down, it would prove his innocence. But, if some of court officials thought that water did not accept him, because he managed to stay on surface for a while, it would be sure sign of his guiltiness.

Trial by duel or judicial duel was performed, very often in praxis, as a typical irrational evidentiary action. According to rules, this ordeal was realized in the presence of princely and city delegates to show the balance between positon of princely governing and importance of city as an integrated social community. Conflicted parties fought with clubs. The winning party got recognition that he was right in particular matter. If women acted in judicial duel, they were not allowed to be represented by chosen replacement, but to fight each other directly. However, solely right to replace women in judicial duel used to have monks, priest, ill ones, handicapped persons and juveniles. (Nikolić 2011:250)

Besides some signs of advanced relation to basic social values, as human life and replacing of death sentence by paying fine, the old Russian Code "Ruskaia Pravda" did not avoid the medieval mainstream of using irrational evidentiary actions in determining ways of obtaining and providing proofs. We are convinced, deeply, that this legal source was undoubtedly reflection of medieval man's perception, which is its predominant characteristic overpowering, even slightly, progressive tendencies of Russian lawmakers in the Middle Ages.

\section{REFERENCES}

Cedrenus, G., (1838) Synopsis historion, Bonn, Deutschland.

Jelačić, A., (1929) Istorija Rusije, Srpska književna zadruga, Beograd.

Kaiser, D. H., (1992) The Laws of Rus' - Tenth to Fifteenth Centuries, Charles Schlacks Publisher, Salt Lake City, Utah, USA, pp. 20-34.

Marvazi, T., (1942) Sharaf al-Zamān Tahir Marvazi on China, the Turks and India, Edited by V. Minorsky, The Royal Asiatic Society, London, United Kingdom.

Miljukov, P., Senjobos, Š., Ezenman, L., (1939) Istorija Rusije, Narodna kultura, Beograd.

Nikolić, D., (2000) Drevnorusko slovensko pravo, Službeni list SRJ, Beograd.

Nikolić, D., (2011) Istorija prava - stari i srednji vek, SVEN, Niš.

Porphyrogenitus, C., (1819) De ceremoniis, Bonn, Deutschland.

Psellus, M., (1928) Chronographia, Edited and French translated by E. Renauld, 2 vols., Paris, France.

9 Similar evidentiary action was used in medieval Germany for the purpose of proving criminal offences considering witchery and sorcery (delicta atrocissima) when burns were interpreted. 
The Russian Primary Chronicle, Laurentian Text, (1953) Translated and edited by Samuel Hazzard Cross and Olgerd P. Sherbowitz-Wetzor, The Mediaeval Academy of America, Cambridge, Massachusetts, USA.

Yahya of Antioch, I. S., (1932) Annals, Patrologia Orientalis, Edited and French translated by I. Kratchovsky and A. A. Vasiliev, XXIII, iii, Paris, France.

Duhaimes Timetable of World Legal History, http://www.duhaime.org/LawMuseum/ LawArticle-44/Duhaimes-Timetable-of-World-Legal-History.aspx, 12/04/2017

The Russkaia Pravda, http://www.duhaime.org/LawMuseum/LawArticle-294/1016--TheRusskaia-Pravda.aspx, 14/04/2017 


\section{Sergej V. ULJANOV \\ Ana G. MATOVIĆ}

\section{DOKAZI I RADNJE DOKAZIVANJA U „RUSKOJ PRAVDI“}

\section{ZAKLJUČAK}

Okosnicu predmetnog rada čini izvor starog ruskog prava pod nazivom „Ruska pravda“, koji predstavlja svojevrsnu sliku ruskog društva na prelasku iz ranog u razvijeni srednji vek. Težnja autora je da prikaže hijerarhiju u odnosima društvenih kategorija prvih ruskih entiteta, te njihovu strukturu uslovljenu geopolitčkim uticajima liderskih državnih zajednica na prostorima Skandinavije i Vizantije. U radu se najpre analiziraju eksterni faktori oblikovanja početaka ruske državnosti. Potom, autor sagledava značaj temelja ruskog srednjovekovnog zakonodavstva, kako bi izdvojio posebnu važnost „Ruske pravde“ za očuvanje sistema vitalnih vrednosti tadašnjeg ruskog društva. Autor esencijalno posvećuje pažnju dokaznim sredstvima predviđenim u „Ruskoj pravdi“, kao naročitom izrazu shvatanja društvenih vrednosti onovremenog čoveka i ključnim činiocima modela odbrane tih vrednosti. Državnopravnu osobenost srednjovekovne Rusije u ovom radu autor ilustruje detaljnim pregledom normativnih rešenja sadržanih u „Ruskoj pravdi“, kao jednom od nosećih stubova rane institucionalizacije društvenopolitičkog miljea ondašnje Rusije.

Ključne reči: dokazi, radnje dokazivanja, Ruska pravda, krivičnoprocesno pravo, srednji vek.

Rad je predat 31. jula 2019. godine, a nakon mišljenja recenzenata, odlukom odgovornog urednika Baštine, odobren za štampu. 